\title{
PREZENTACJE
}

Maria Radziszewska

DOI: $10.14746 /$ bhw.2017.37.11

Uniwersytet Warmińsko-Mazurski

w Olsztynie

\section{Wyjazd studyjny polskich historyków wychowania do Rumunii}

Staż naukowy odbywał się w dniach od 11 do 18 czerwca 2017 r. na zaproszenie Związku Polaków w Rumunii, którego prezesem jest Gerwazy Longher.

Cel stażu dotyczył poznania rumuńskiego systemu edukacji na poziomie podstawowym i średnim, a także systemu kształcenia szkolnictwa wyższego oraz zapoznania się z działalnością oświatową, naukową i społeczną Związku Polaków w Rumunii.

Uczestnikami wyjazdu byli naukowcy, wykładowcy i doktorantka z pięciu polskich uczelni. Grupę tę reprezentowali: dr Ewa Barnaś-Baran (Katedra Historii i Teorii Wychowania, Wydział Pedagogiczny Uniwersytetu Rzeszowskiego), mgr Bohdan Głębocki (Zakład Informacji Naukowej, Wydział Pedagogiczno-Artystyczny w Kaliszu, Uniwersytet Adama Mickiewicza w Poznaniu), prof. UAM. dr hab. Piotr Gołdyn (Zakład Pedagogiki, Wydział Pedagogiczno-Artystyczny w Kaliszu, Uniwersytet Adama Mickiewicza w Poznaniu), dr Anna Haratyk (Zakład Historii Edukacji, Instytut Pedagogiki, Uniwersytet Wrocławski), dr Mirosław Piwowarczyk (wicedyrektor Instytutu Pedagogiki ds. dydaktyki i jakości kształcenia Uniwersytetu Wrocławskiego), dr Maria Radziszewska (Katedra Dydaktyki i Historii Wychowania, Wydział Nauk Społecznych, Uniwersytet Warmińsko-Mazurski w Olsztynie) oraz mgr Karolina Sigda (Katolicki Uniwersytet Lubelski Jana Pawła II, Wydział Nauk Społecznych).

W programie stażu naukowego znalazły się wizyty studyjne, spotkania, rozmowy i konsultacje. Dotyczyły one zagadnień z zakresu systemu szkolnictwa w Rumunii, organizacji roku szkolnego i akademickiego, rozpoznawania systemu jakości kształcenia, awansów i rozwoju kadry naukowej, możliwości kwerendy archiwalnej i bibliotecznej zagranicą, szkolnictwa dla mniejszości polskiej w Rumunii, sytuacji Polaków w Rumunii. 
Program pobytu naukowego obejmował wizytę w:

- Uniwersytecie Aleksandra Jana Cuzy w Jassach i w Muzeum Uniwersyteckim,

- Uniwersytecie Stefana Wielkiego w Suczawie,

- Szkole Podstawowej im. Henryka Sienkiewicza w Nowym Sołońcu,

- siedzibie Związku Polaków w Rumunii w Suczawie i w siedzibach Domów Polskich na Bukowinie.

\section{Uniwersytet im. Aleksandra Jana Cuzy w Jassach}

Uniwersytet im. Aleksandra Jana Cuzy w Jassach (UAIC) powstał 26 października 1860 r. Początek jego akademickości dały trzy pierwsze wydziały: prawa, filozofii i teologii. Obecnie w jego strukturze znajduje się 14 wydziałów. Na Wydziale Filologicznym UAIC w Jassach prowadzony jest lektorat języka polskiego.

Początki uniwersytetu sięgają, założonej pod wpływem podróży po Polsce, szkoły łacińskiej w Cotnari niedaleko Jass przez hospodara Jana Jakuba Heraklida Despoda. Szkoła (Colegiile de la Cotnari) funkcjonowała tylko rok (1562-1563), dopiero Piotr V Kulawy ją odnowił. Kolejny etap w drodze do uniwersytetu to szkoła Trzech Hierarchów (Trei Ierarchi) powołana 9 maja 1640 r. przez hospodara Vasile Lupu. W tym samym czasie przy szkole zorganizowano też pierwszą bibliotekę. W jej zbiorach znalazły się książki łacińskie, greckie, cerkiewno-słowiańskie, włoskie oraz polskie. Nauka w szkole Trei Ierarhi odbywała się w języku greckim, stąd nazywana była szkołą grecką. Burzliwe czasy, obfite w wojny mołdawsko-polskie i rosyjsko-tureckie, wpływały na funkcjonowanie szkoły greckiej. W 1714 r. szkoła grecka została ponownie otwarta przez władcę mołdawskiego Nicolae Mavrocordata i otrzymała nazwę Akademia Królewska. Akademia funkcjonowała w latach 1714-1821. Wtedy to wraz z akademią w Bukareszcie została zamknięta. Ponownego otwarcia i reorganizacji szkoły dokonał kolejny władca Mihail Sturdza. 16 czerwca 1835 roku nadał szkole imię Akademia Mihaileana. W powstanie Akademii, ale także rozwój szkolnictwa narodowego w Mołdawii, należy podkreślić wkład Gheorghe Asachi (1788-1869). Asachi wykształcony m.in. w uniwersytecie józefińskim we Lwowie, zainicjował w 1829 r. wykłady z inżynierii w języku rumuńskim w Akademii Mihaileana. (Dzięki niemu powstał pierwszy instytut kształcenia dziewcząt (1834), założył też szkoły zawodowe (1841) i dał podwaliny pod szkolnictwo wyższe techniczne (1813 szkoła inżynierów)). W latach 1847-1851, za sprawą władcy Grigore Ghica, językiem wykładowym był język francuski. W Akademii Mihaileana funkcjonowały trzy wydziały: filozofii, prawa i teologii, które następnie weszły w struktury Uniwersytetu w Jassach ufundowanego przez księcia Aleksandra Jana Cuzę. Uniwersytet powstał w rok po zjednoczeniu dwóch królestw rumuńskich.

Pierwszą wizytą w programie były spotkania z pracownikami naukowymi Uniwersytetu w Jassach. Niezwykle gościnnie przyjął polską grupę Prof. univ. dr. Laurenţiu Rădvan Directorul Departamentului de Istorie oraz asist. univ. dr. Bogdan Ceobanu. Prof. Laurențiu Rădvan przedstawił historię Jass, przybliżył też wątki polskie w dzie- 
jach tego miasta. Następnie między naukowcami z Rumunii i Polski wywiązała się dyskusja wokół szkolnictwa wyższego. Poruszano takie kwestie, jak: awans i rozwój naukowy kadry, kształcenie studentów, system jakości kształcenia. Za sprawą nauczycielki języka rumuńskiego Eleny Larco, tłumaczki i przewodniczki w jednej osobie, mieliśmy okazję zwiedzać muzeum uniwersyteckie (Muzeul Universităţii „Alexandru Ioan Cuza” din Iaşi). Muzeum ma dwie stałe wystawy. Pierwsza poświęcona jest cywilizacji Cucuteni, zaś druga to wystawa akademicka. Po wystawach muzealnych oprowadzał nas dr kurator Marian Hariuc.

W czasie spaceru po Jassach zatrzymaliśmy się przed najstarszym budynkiem szkolnym w mieście, w którym mieści się Scole Gheorche Asachi.

\section{Uniwersytet Stefana Wielkiego w Suczawie}

Uniwersytet Stefana Wielkiego w Suczawie (USV) powstał 7 maja 1990 r. Początek szkolnictwu uniwersyteckiemu w Suczawie dał Instytut Pedagogiczny otwarty 1 października 1963 r. Jego pierwszym rektorem był pisarz, krytyk i historyk literatury prof. univ. dr. Constantin Ciopraga. Od 1975 r. Instytut powoli przeobrażał się zgodnie z systemem politycznym w kierunku kształcenia technicznego. Obecnie w USV funkcjonuje 10 wydziałów.

W czasie drugiej wizyty zwiedzaliśmy kampus uniwersytecki pod przewodnictwem prof. dr Olimpii Mitric i Simony Sărohe. Zwizytowaliśmy m.in. sale wykładowe i ćwiczeniowe, czytelnie, bibliotekę, wypożyczalnię, magazyn biblioteczny, obiekt sportowy $\mathrm{z}$ basenem, centrum konferencyjne, pomieszczenia pracownicze.

Spotkaliśmy się też z Dyrektor Zakładu Nauk o Wychowaniu prof. univ conf. Otylią Clipă. Zakład funkcjonuje w strukturze Wydziału Nauk o Edukacji. Zajmuje się kształceniem nauczycieli dla potrzeb szkolnictwa podstawowego i przedszkoli. Studenci odbywają praktyki w przedsiębiorstwach i szkołach na terenie miasta i województwa Suczawa, jak również zagranicą w ramach programu Erasmus. Zakład współpracuje z wieloma ośrodkami zagranicznymi, w tym również z uczelniami polskim np. w Białymstoku i w Kielcach.

\section{Szkoła Podstawowa im. Henryka Sienkiewicza w Nowym Sołońcu}

Początki szkolnictwa w Nowym Sołońcu sięgają lat 50. XIX stulecia. Wtedy to we wsi pojawił się pierwszy nauczyciel, który nauczał w systemie dwuklasowym. W 1865 r. zbudowano budynek szkolny. Obecny budynek szkolny został wybudowany na miejscu starej szkoły i oddany do użytku w 1995 r. Pełni on rolę największej placówki oświatowej na rumuńskiej Bukowinie, gdzie wciąż prowadzone są lekcje języka polskiego ojczystego. Od 2002 r. szkoła w Nowym Sołońcu, jak również inne polskie szkoły, została objęta programem edukacyjno-pomocowym „Dzieci Bukowiny”. Głównym założeniem 
programu jest szerszy dostęp do edukacji dzieci polonijnej oraz poprawa systemu ich kształcenia.

Do szkoły w Nowym Sołońcu w roku szkolnym 2016/17 uczęszczało 82 uczniów do klas od 0 do VIII. Do przedszkola było zaś zapisanych 32 dzieci. Zajęcia przedszkolne odbywają się w godzinach od 8.00 do 12.00 , natomiast szkoła jest czynna trzy godziny dłużej. Edukacja dzieci i młodzieży polskiej w Nowym Sołońcu odbywa się w sekcjach polskich w szkole narodowej, gdzie język polski nauczany jest w ramach zajęć dodatkowych. W klasie 0 są 3 h języka polskiego, w klasach od I do IV - 4 godziny, natomiast w klasach V-VIII (poziom wyższy gimnazjalny) uczniowie mają tygodniowo 3 godziny języka ojczystego. Ponadto nauka języka polskiego w wymiarze 2 godziny tygodniowo obejmuje też dzieci 6-letnie. Nauczycielką języka polskiego jest dr Maria Ostrovschi Chahula. Nauczanie języka polskiego odbywa się na wniosek rodziców. Kurs zostaje uruchomiony dla 10 osób. W języku polskim w szkołach rumuńskich można też nauczać religii i muzyki z rytmiką. Pewnym ułatwieniem w poznawaniu własnego języka, kultury dla gimnazjalistów polonijnych (klasy V-VIII) jest przedmiot „Historia i tradycja mniejszości narodowych". Jednak do jego prowadzenia brakuje podręczników. W nowosołonczańskiej szkole uczniowie nie wypełniają do końca obowiązku szkolnego, który trwa do 16 roku życia, czyli ukończenia IX klasy. Zatem po ukończeniu klasy VIII przystępują do egzaminu kompetencyjnego z matematyki i języka rumuńskiego. Pozytywny wynik egzaminu otwiera im drogę do dalszego kształcenia np. w liceum w Gura Humorului, w którym jest prowadzona klasa polska.

Podczas naszej wizyty w Szkole Podstawowej im. Henryka Sienkiewicza w Nowym Sołońcu spotkaliśmy się z nauczycielką przedszkola Iulianą Ciorneli oraz nauczycielką języka polskiego Marią Ostrovschi Chahula. Wysłuchaliśmy polsko-rumuńskiego występu artystycznego w wykonaniu dzieci przedszkolnych.

\section{Związek Polaków w Rumunii}

Związek Polaków w Rumunii istnieje od 1990 r. Został zarejestrowany 16 marca 1990 r. jako Związek Polaków w Rumunii „Dom Polski” w Bukareszcie. Początkowo organizacja polonijna działała w Bukareszcie, tam też w 1991 r. zaczęto wydawać dwujęzyczne pismo „Polonus”. Po II Zjeździe Związku Polaków w Rumunii, który miał miejsce w dniach 13-14 kwietnia 1991 r., siedzibę organizacji przeniesiono do Suczawy. Od tego momentu Związek stał się organizacją federacyjną, czyli zrzesza lokalne organizacje polonijne - Stowarzyszenia Polaków. W roku 2015 było 14 Stowarzyszeń Polaków w następujących miejscowościach: Bukareszt, Gura Humorului, Jassy, Kaczyka, Konstanca, Moara, Nowy Sołoniec, Paltinoasa, Plesza, Pojana Mikuli, Radowce, Ruda, Siret, Suczawa. Wśród wymienionych, większość miejscowości znajduje się na Bukowinie, ale Polacy też zamieszkują na całym terenie Rumunii. Stanowią jedną z 20 grup posiadających status mniejszości narodowej w Rumunii, a Związek Polaków w Rumunii jest jedną z 19 organizacji uznanych przez rząd rumuński. Polacy mają również swojego posła 
w Parlamencie Rumunii. Pierwszym z nich był Antoni Linzmaier, następnie Jan Piotr Barbasz, Gerwazy Longher, a obecnie pierwszą kadencję poselską pełni Victoria Longher.

Strukturę Związku Polaków w Rumunii tworzy pięcioosobowy Zarząd oraz prezesi 14 lokalnych filii z całego kraju. Od początku istnienia Związku jego prezesami kolejno byli: Xenia Grabska-Stoica, Antoni Rojowski, Jan Piotr Babiasz. Od 2002 r. funkcję prezesa organizacji polonijnej pełni Gerwazy Longher.

Podczas wizyty w siedzibie Związku Polaków w Rumunii spotkaliśmy się z Elżbietą Wieruszewską-Calistru, która omówiła nam działalność tej organizacji polonijnej. Przybliżyła nam formy aktywności oświatowo-kulturalnej służące zachowaniu tożsamości Polaków w Rumunii. Największym przedsięwzięciem w tym zakresie są organizowane od 1998 r. Dni Polskie, łączące sympozjum naukowe z cyklem imprez kulturalnych. Od 2002 r. odbywają się one pod hasłem „Bliżej siebie”, aby wzmocnić działania na rzecz wzajemnego polsko-rumuńskiego poznania i zbliżenia. Stałą pracą Związku Polaków w Rumunii jest działalność wydawnicza („Polonus”, „Mały Polonus”, monografie z sympozjów, monografie wsi i parafii itp.). Podczas spotkania wywiązała się dyskusja dotycząca sytuacji szkolnictwa polonijnego w Rumunii. Nasza prelegentka przedstawiła nam możliwości edukacji polskich dzieci w województwie suczawskim, gdyż na tym terenie jest największe skupisko ludności polskiego pochodzenia w Rumunii. Dzięki uprzejmości pracowników Związku Polaków w Rumunii mieliśmy możliwość zapoznania się z księgozbiorem bibliotecznym, otrzymaliśmy też kilka publikacji w prezencie. Również ze swej strony przekazaliśmy książki dla polskich dzieci w Rumunii.

Życie polonijne w Rumunii toczy się wokół Domów Polskich, które administruje Związek Polaków w Rumunii. W Suczawie Dom Polski przy ulicy Ioana Vodă Viteazu nr 5, wybudowany w latach 1903-1907 staraniem członków Towarzystwa Bratniej Pomocy i Czytelni Polskiej, stanowi jednocześnie siedzibę Związku Polaków w Rumunii. Spotkania lokalnych Stowarzyszeń Polaków odbywają się także w Domach Polskich w Bukareszcie, Jassach, Kaczyce, Nowym Sołońcu, Pleszy, Pojanie Mikuli, Paltinoasie, Radowcach, Rudzie, Sirecie. Niebawem zostanie oddany do użytku Dom Polski w Moarze, gdzie trwa jego budowa. Domy Polskie to nie tylko miejsca spotkań, ale też miejsca wspólnych działań lokalnych społeczności. To w nich organizowane jest także nauczanie języka polskiego.

Poza kursami języka polskiego prowadzonymi przez Domy Polskie czy szkolny punkt konsultacyjny w Bukareszcie, język polski można też studiować na Uniwersytetach w Jassach, w Krajowej, w Klużu i w Bukareszcie. Ponadto lektorzy języka polskiego wymienionych uczelni często zasiadają w jury organizowanej od 2013 r. Krajowej Olimpiady Języka Polskiego Ojczystego. Ten etap jest przepustką do Olimpiady Literatury i Języka Polskiego w Warszawie. Gimnazjaliści i licealiści z województwa suczawskiego rokrocznie biorą udział w tej olimpiadzie i odnoszą sukcesy. W dniach 10-11 marca 2017 r. w skład komisji egzaminacyjnej konkursu krajowego jako lektorzy weszli Anna Musiał z Uniwersytetu w Klużu oraz Dariusz Kasprzyk z Uniwersytetu w Jassach. 


\section{Dom Polski w Pleszy}

Plesza, to polska wieś założona 181 lat temu przez Górali czadeckich. Obecnie zamieszkiwana jest przez ok. 70 rodzin. Jej mieszkańcy żyją w trudnych warunkach, często za chlebem udają się do pracy za granicę. Wieś położona jest na górze Plesz $(734 \mathrm{~m}$ n.p.m.), na której szczycie wybudowano w stylu romańskim w 1904 r. kościół pw. św. Anny. Obok kościoła jest nowy cmentarz i dom parafialny, gdyż 1 września 2013 r. Plesza została ustanowiona samodzielną parafią. Jej pierwszym proboszczem został student teologii Katolickiego Uniwersytetu Lubelskiego Jana Pawła II - ks. Andrzej Staszkowian. W roku 1906 we wsi powstał budynek szkolny, w którym naukę w czterech klasach zorganizował polski nauczyciel Józef Lechowicz. W tym samym roku, w budynku szkolnym rozpoczęła działalność Czytelnia Towarzystwa Szkoły Ludowej. Do 2010 r. funkcjonowała w Pleszy szkoła i przedszkole, obecnie dzieci i młodzież uczęszczają do szkół w gminie Monăstirea Humorului. (Na poziomie podstawowym jest to Szkoła Podstawowa i Przedszkole nr 2 im. Krystyny Bochenek w Pojanie Mikuli. Natomiast klasy od IX do XII prowadzi m.in. Colegiul „Alexandu cel Bun” w Gura Humorului, w którym pracuje Anetta Buzuk, nauczycielka języka polskiego skierowana do pracy dydaktycznej przez Ośrodek Rozwoju Polskiej Edukacji Za Granicą.) W miejsce dawnej szkoły, staraniem Związku Polaków w Rumunii, w 2014 r. oddano do użytku nowy budynek Domu Polskiego w Pleszy, którym opiekuje się Edviga Alexandrovici. Dom Polski stał się siedzibą lokalnego Stowarzyszenia Polaków, które w Pleszy istnieje od czerwca 1991 r. 24 lipca 2016 r. z okazji 180-lecia Pleszy odbyły się uroczyste obchody, w których udział wzięła m.in. delegacja Senatu Rzeczypospolitej Polskiej reprezentowana przez senatorów Artura Warzochę i Janą Marię Jackowskiego, przedstawicieli Ambasady RP w Bukareszcie, władz Związku Polaków w Rumunii oraz duchowieństwa na czele z Petru Gherghel, biskupem diecezji Jassy.

Będąc w Pleszy, spotykaliśmy się z mieszkańcami, uczestniczyliśmy w nabożeństwie Bożego Ciała, zwiedzaliśmy wioskę, stary cmentarz, na którym znajduje się krzyż i kapliczka pw. Świętego Jana Pawła II. Podziwialiśmy też autorstwa miejscowego artysty rzeźbiarza i poety Bolka Majerika wyryte w piaskowców potężne płaskorzeźby.

Staż naukowy w Rumunii przypadł w okresie zakończenia roku szkolnego i sesji egzaminacyjnej w uniwersytetach. Byliśmy świadkami rozdania dyplomów na zakończenie szkoły podstawowej poziomu niższego, który miał miejsce na scenie w Muzeum Wsi Bukowińskiej w Suczawie. Oprócz życia szkolnego i uniwersyteckiego, na szlaku jaki wiódł przez Satmar, Maramuresz, Bukowinę i Mołdawię, mieliśmy możliwość zobaczenia codziennego życia Rumunów oraz polskiej mniejszości. Zwiedzając polskie wioski, zauważyliśmy z jakim przywiązaniem do polskości, ich mieszkańcy pielęgnują tradycje, kulturę i język naszych wspólnych przodków.

Ostatnim nie planowanym punktem naszej podróży naukowej, w związku z obchodami 500-lecia reformacji, było zwiedzanie Kolegium Reformacji w Sárospatak na Węgrzech, gdzie w latach 1650-1654 pracował i tworzył „,nauczyciel Europy” Jan Amos Komeński. Wątki reformacyjne na północy Węgier odnaleźliśmy też w oddalonym o ponad 40 km od Sárospatak w mieście Nyíregyháza. 
W dyskusji podsumowującej stażyści wyrazili nadzieję, że staż naukowy spełnił rolę międzynarodowej wymiany poglądów, doświadczeń i perspektyw zorientowanych na wspólne badania naukowe. 
